\title{
Finance, Islamic Fiancé: Theoretical Analysis
}

\author{
Mahbuba Zaman \\ Independent Researcher
}

\begin{abstract}
The paper discusses the steps to be taken to strengthen the efficiency and transparency of the Board and management. Increasing shareholders and depositors to play a more important role in protecting their own interests. The article then describes some of the popular resources available to enhance the effectiveness and responsibility of the Board and the Executive.
\end{abstract}

Keywords: Finance, Islamic Finance.

\section{Introduction}

Islamic finance means that debt creation by direct lending and borrowing from money or other financial assets is not permitted. The debts can only be created by selling or leasing real assets through leasing-based financing (such as murabaha, ijara, and sukuk). The assets rented or sold have to be real (construction, real estate or other physical infrastructure), and the trans actions must be genuine (approved by government regulators as well as Shariah board religious experts) with full intent to give and take charge; the associated debt (risk) cannot be sold and transferred to another person.

\section{Theoretical Analysis}

Financial services that meet the requirements of the Shariah, or Islamic law are called Islamic finance. While designed to meet the specific religious requirements of Muslim customers, Islamic banking is not restricted to Muslims: both the financial services provider and the customer can be non-Muslim, as well as Muslim. Shariah-compliant financing (SCF) constitutes financial practices that conform to Islamic law. Major principles of shariah law that are applicable to finance and that differ from conventional finance are: In conventional forms of finance, a distinction is made between acceptable interest and usurious interest (i.e., excessive rates of interest). In contrast, under Islamic law, any level of interest is considered to be usurious and is prohibited. Some question how lenders can profit from financial transactions under Islamic law. Take for instance, in a real estate setting; SCF takes the form of leasing, as opposed to loans. Instead of borrowing money, the bank obtains the property and leases it to the Shariah-compliant investor, who pays rent instead of interest. Ban on

Uncertainty in contractual terms and conditions is not allowed, unless all of the terms and conditions of the risks are clearly understood by all parties of a financial transaction. This condition may help eliminate most of the speculative transactions which involve gharar (excessive uncertainty).Parties involved in a financial transaction must share both the associated risks and profits. Earnings from profits or returns from assets are permitted, so long as the business risks are shared by the lender and the borrower.

\section{Conclusion}

This will help ensure that the seller (or lessor) also shares a part of the risks in order to be able to get a share of the returns. Once the seller (financier) acquires ownership and possession of the goods for sale or lease, he/she bears the risks. Investment in industries that are prohibited by the Qur'an, such as alcohol, pornography, gambling, and pork based products, are discouraged. Each financial transaction must be tied to a "tangible, identifiable underlying asset."9The debt cannot be sold, and thus the risk associated with it cannot be transferred to someone else; it must be borne by the creditor himself. According to this condition a transaction must be a genuine trade transaction, and the fact that the creditor cannot transfer the risk to someone else by selling off the debt, will also help eliminate speculative and derivative transactions, as well as prevent the debt from rising far above the size of the real economy

\section{References}

Alam, I., Islam, K. A., \& Al-Amin, D. M. (2015). Human Resource Practices \& Gender Discrimination in Asian Countries. International Journal of Innovative Research and Creative Technology, I(3). Retrieved from http://www.ijirct.org/viewPaper.php?paperId=IJIRCTI20I057

Chowdhury, S., Hasan, K. R., Rahman, M., Islam, K. A., \& Mohammad, N. (2020). Causal Relationship among Carbon Dioxide (CO2) Emissions, Renewable Energy, Population and Economic Growth in Bangladesh: An Empirical Study. , Research in World Economy, II(6). https://doi.org/I0.5430/rwe.vI In6pI96 
Hasan, Z., \& Islam, K. M. A. (2020). Academic, Financial and Administrative Issues of Online Teaching During Corona Pandemic: The Scenario of Private Universities in Bangladesh. International Journal of Accounting \& Finance Review, 5(I), I I6-I22. https://doi.org/I0.4628I/ijafr.v5iI.630

Hossain, S. A., Islam, M. N., Mahmud, M. S., \& Islam, K. A. (2017). Evaluation of Financial Performance of Commercial Banks in Bangladesh: Comparative Study Based on CAMEL Approach. The Millennium University Journal, 2(I), 54 77. Retrieved from http://www.themillenniumuniversity.edu.bd/journal/index.php/TMUJ/article/view/22

Hossain, S. A., \& Islam, K. M. A. (2017). Impact of Basel II \& III Implementation to Mitigate Bank Risk: A Study on AlArafah Islami Bank Limited. Indian Journal of Finance and Banking, I(2), 42-5I. https://doi.org/I0.4628I/ijfb.vIi2.88

Hossain, S. A., \& Islam, K. A. (2015). The Relationship of the Macroeconomic Variables with the Growth of Garment Industry in Bangladesh. Global Disclosure of Economics and Business, 4(I), 63-78. https://doi.org/IO.I8034/gdeb.v4iI.I53

Islam, K. A. (2012). Performance Evaluation of the Banking Industry in Bangladesh: A Comparative Analysis. IOSR Journal of Business and Management (IOSRJBM), 3(4),9-I9. https://doi.org/I0.9790/487X-03409I9

Islam, K. M. A., \&Zaman, M. (20I3). Job satisfaction \& bankers' turnover: a case study on Bangladesh commerce bank limited. International Journal of Business and Management Review, I(4), I-I4. Retrieved from https://www.eajournals.org/journals/international-journal-of-business-and-management-review-ijbmr/vol-I-issue4-december-2013/job-satisfaction-bankers-turnover-a-case-study-on-bangladesh-commerce-bank-limited/

Islam, K. A., Hossain, S. A., Zaman, M., \& Miajee, M. R. K. (2013). Poverty Alleviation in Bangladesh through Small and Medium Enterprise (SME) Loan: A Case Study on United Commercial Bank Limited at Gulshan Branch. Bangladesh Research Foundation Journal, 2(3),29-43.

Islam, K. A. (2013). Examination of Profitability in Private Commercial Banks in Bangladesh: An Empirical Investigation. Bangladesh Research Foundation Journal, 2(2),29,68-83.

Islam, K. A., Alam, I., \& Hossain, S. A. (20I4). Examination of profitability between Islamic banks and conventional banks in Bangladesh: A comparative study. Research in Business and Management, I(I), 78-89. https://dx.doi.org/I0.5296/rbm.vIiI.4894

Islam, K. A. (20I4). Foreign Direct Investment (FDI) in Bangladesh: Prospects and Challenges and Its Impact on Economy. Asian Business Review, 4(I), 24-36. https://doi.org/I0.18034/abr.v4iI.70

Islam, K. A., \& Salma, U. (20I4). Customer satisfaction of Internet banking in Bangladesh: A case study on Citibank NA. Asian Journal of Applied Science and Engineering, 3(I), 5I-62. Retrieved from https://www.journals.abc.us.org/index.php/ajase/article/view/5I-62

Islam, K. A. (20I4). Measurement of Capital Adequacy of AB Bank Limited. International Journal of Novel Research in Marketing Management and Economics, I(I), 24-39. Retrieved from https://www.noveltyjournals.com/journal/IJNRMME/Issue-I-September-20I4-December-20I4/0

Islam, K. A. (20I5). Throughput accounting: a case study. International Journal of Finance and Banking Research, I(2), I9-23. https://doi.org/I0.I1648/j.ijfbr.20150102.II

Islam, K. M., \& Hossain, S. (20I5). Demutualization of Dhaka Stock Exchange: Opportunities and Challenges. International Journal of Finance and Banking Research, I(I), I-II. Retrieved from http://article.sciencepublishinggroup.com/html/I0.I I648.j.ijfbr.20I50I0I.I I.html

Islam, K. A., Alam, I., \& Al-Amin, D. M. (2015). Foreign exchange operation of private commercial banks in Bangladesh: A case study on AB Bank Limited. International Journal of Innovative Research and Creative Technology, I(3). Retrieved from http://www.ijirct.org/viewPaper.php?paperId=IJIRCTI20I06I

Islam, K. A., \& Salma, U. (20I6). The role of private universities in higher education of Bangladesh: an empirical investigation. International Journal of Finance and Banking Research, 2(4), I2I-I28. https://doi.org/IO.II648/j.ijfbr.20I60204.II

Islam, K. A., \& Salma, U. (2016). Mobile Banking Operations and Banking Facilities to Rural People in Bangladesh. International Journal of Finance and Banking Research, 2(4), I47. https://doi.org/I0.I I648/j.ijfbr.20160204.I4

Islam, K. A. (2016). Impact of Micro-Financing on Women Empowerment in Bangladesh. The Millennium University Journal, I(I), I-I8. Retrieved from http://www.themillenniumuniversity.edu.bd/journal/index.php/TMUJ/article/view/I 
Islam, K. A., \& Salma, U. (2016). The Renewable Energy and Sustainable Development: A Case Study of Bangladesh. International Journal of Finance and Banking Research, 2(4), I39-I46. https://doi.org/IO.I I648/j.ijfbr.20160204.13

Islam, K. A. (2016). Rural Development Scheme: A Case Study on Islami Bank Bangladesh Limited. International Journal of Finance and Banking Research, 2(4), I29. https://doi.org/I0.I I648/j.ijfbr.20160204.12

Islam, K. M. A. (2016). Financial Performance Comparison of Top Rated Banking Financial Institutions (BFIs) of Bangladesh. $\begin{array}{llll}\text { Indian Journal of } & \text { Science, } & \text { 23(85),669-697.Retrieved }\end{array}$ https://discoveryjournals.org/science/current_issue/2016/A60.pdf

Islam, K. M. A. (2016). Corporate Governance: Conjecture and Modernism, Indian Journal of Science,23(86), 7988I7.Retrieved from https://discoveryjournals.org/science/current_issue/2016/A66.pdf

Islam, K. M. A. (2016). Factors Influencing Consumers Purchase Decision: A Case Study of Pantene Shampoo. Indian Journal of Science, 23(88),9I0-923.Retrieved from https://discoveryjournals.org/science/current_issue/20I6/A74.pdf

Islam, K. M. A., \& Barghouthi, O. (2017). Human Resource Management: An Islamic Perspective. International Journal of Islamic Business \& Management, I(I), IO-I3. https://doi.org/I0.4628I/ijibm.vIiI.46

Islam, K. M. A., \& Barghouthi, O. A. (2017). Corporate Governance: An Islamic Institution Perspective. International Journal of Islamic Banking and Finance Research, I(I), 29-32. https://doi.org/I0.4628I/ijibfr.vIiI.36

Islam, K. A. (2017). An Empirical Research on Beximco Knitting Ltd: Ratio, DuPont, Valuation and Pro-Forma Analysis. Indian Journal of Finance and Banking, I(I), I-7. https://doi.org/I0.4628I/ijfb.vIiI.80

Islam, K. M. A. (2017). Finance: An Islamic Perspective. International Journal of Islamic Banking and Finance Research, I(I), I-5. https://doi.org/I0.4628I/ijibfr.vIiI.32

Islam, K. M. A., \& Barghouthi, O. A. (2017). An Islamic Perspective of Marketing. International Journal of Islamic Business \& Management, I(I), I7-I9. https://doi.org/I0.4628I/ijibm.vIiI.48

Islam, K. M. A., \& Karim Miajee, M. R. (2017). An Islamic Perspective of Leadership. International Journal of Islamic Business \& Management, I(I), I4-I6. https://doi.org/I0.4628I/ijibm.vIiI.47

Islam, K. M. A., \& Karim Miajee, M. R. (2017). Business Ethics: An Islamic Perspective. International Journal of Islamic Business \& Management, I(I), 7-9. https://doi.org/I0.4628I/ijibm.vIiI.45

Islam, K. M. A., \& Barghouthi, O. A. (2017). Risk Management of Islamic Banking: An Islamic Perspective. International Journal of Islamic Banking and Finance Research, I(I), 25-28. https://doi.org/I0.4628I/ijibfr.vIiI.35

Islam, K. A. (2017). An Empirical Research on Fu-Wang Foods Ltd: Industry, Strategy, Accounting, Ratio, Valuation and Proforma Analysis. American Finance \& Banking Review, I(I), I-II. https://doi.org/I0.4628I/amfbr.vIiI.79

Islam, K. M. A. (2017). Predicament and Thought of SMEs Financing in Bangladesh: An Exploratory Research.Indian journal of arts,7(22), I46-I5I.Retrieved from https://discoveryjournals.org/arts/current_issue/2017/AI7.pdf

Islam, K. A., \& Miajee, M. R. K. (2018). Small and Medium Enterprises (SMEs) Financing in Bangladesh: A Review of Literature. International Journal of Small and Medium Enterprises, I(I), II-I5. https://doi.org/I0.4628I/ijsmes.vIiI.62

Islam, K. M. A., \& Karim Miajee, M. R. (2018). Exploring E-Business in SMEs. International Journal of Small and Medium Enterprises, I(I), I6-I8. https://doi.org/I0.4628I/ijsmes.vIiI.63

Islam, K. M. A., \& Barghouthi, O. A. (2018). To What Extent Do the Investment Programs in the Infrastructure Sector Comply with the Determinants of National Competitive Advantage?. International Journal of Small and Medium Enterprises, I(I), 6-IO. https://doi.org/I0.4628I/ijsmes.vIiI.6I

Islam, K. M. A., \& Barghouthi, O. A. (2018). To What Extent Do the Investment Programs in the Small and Medium Enterprises Sector Comply with the Determinants of National Competitive Advantage?. International Journal of Small and Medium Enterprises, I(I), I-5. https://doi.org/I0.4628I/ijsmes.vIiI.60

Islam, K. A., \& Bhuiyan, A. B. (2019). The Theoretical Linkages between the Shariah Supervisory Board (SSB) and Stakeholder Theory in the Islamic Financial Institutes: An Empirical Review. International Journal of Accounting \& Finance Review, 4(2), 43-49. https://doi.org/I0.4628I/ijafr.v4i2.436

Islam, K. A. (2019). What Do the Customers Think?An Evaluation of New Products \& Services of National Bank Limited. Retrieved from https://www.cribfb.com/pdf/Thesis_20I7_0I.pdf 
Nayeen, C. J., Islam, K. A., Chowdhury, F. N., \& Zayed, N. M. (2020). Testing Communicative Language Teaching (CLT) through English for Today (EFT) in Bangladesh: Challenges Faced by Tertiary Students Initially. American International Journal of Education and Linguistics Research, 3(2), I9-27.

Kader, S. A., Zayed, N. M., Khan, S., Islam, K. M. A., \& Siddiki, M. N. A. (2019). An Analysis of Socio-Economic Condition of Female Readymade Garments' (RMG) Workers in Dhaka City. The Millennium University Journal , 4(I), I2-20. Retrieved from http://www.themillenniumuniversity.edu.bd/journal/index.php/TMUJ/article/view/26

Hasan, Z., \& Islam, K. M. A. (2020). Academic, Financial and Administrative Issues of Online Teaching During Corona Pandemic: The Scenario of Private Universities in Bangladesh. International Journal of Accounting \& Finance Review, 5(I), I I6-I22. https://doi.org/I0.4628I/ijafr.v5iI.630

Barghouthi, O. A., \& Islam, K. M. A. (2020). Financial Stability Implications of Stress Testing for Risk Taking and Credit Growth. American Finance \& Banking Review, 5(2), I-4. https://doi.org/I0.4628I/amfbr.v5i2.778

Ali, M. C., Islam, K. M. A., Chung, S., Zayed, N. M., \& Afrin, M. (2020). A Study of Green Human Resources Management (GHRM) and Green Creativity for Human Resources Professionals. International Journal of Business and Management Future, 4(2), 57-67. https://doi.org/I0.4628I/ijbmf.v4i2.857

Baqir, M., Hussain, S., Waseem, R., \& Islam, K. M. A. (2020). Impact of Reward and Recognition, Supervisor Support on Employee Engagement. American International Journal of Business and Management Studies, 2(3), 8-2I. https://doi.org/I0.46545/aijbms.v2i3.256

Barghouthi, O. A., Shaheen, A. A., Al-Ghazali, S., Islam, K. M. A., \& Barakat, F. S. Q. (2020). IMPEDIMENTS FOR ISSUING SUKUK BONDS FOR IMPROVING ECONOMIC DEVELOPMENT IN PALESTINE. International Journal of Sukuk and Waqf Research, I(I), I-24. Retrieved from https://www.cribfb.com/journal/index.php/IJSWR/article/view/855

Barakat, F. S. Q., Perez, M. V. L., Ariza, L. R., Barghouthi, O. A., \& Islam, K. M. A. (2020). THE IMPACT CORPORATE GOVERNANCE ON INTERNET FINANCIAL REPORTING: EMPIRICAL EVIDENCE FROM PALESTINE. International Journal of Accounting \& Finance Review, 5(4), I-22. https://doi.org/I0.4628I/ijafr.v5i4.852

Hussain, S., Baqir, M., Islam, K. M. A., \& Asif, S. (2020). HOW SELF-CONTROL IMPACT’S ON HAPPINESS AND SATISFACTION WITH LIFE WITH MODERATING ROLE OF LOCUS OF CONTROL. American Economic \& Social Review, 6(2), I3-30. https://doi.org/I0.4628I/aesr.v6i2.85I

Baqir, M., Hussain, S., Islam, K. M. A., \& Waseem, R. (2020). Comparison of Financial Performance of Private Commercial Banks in Pakistan. American Finance \& Banking Review, 5(2), 5-I7. https://doi.org/I0.4628I/amfbr.v5i2.84I

Bhuiyan, A. B., Ali, M. J., Islam, K. M. A., Alam, M. S., \& Solaiman, M. (2020). THE ISSUES AND CHALLENGES OF SHARIAH HARMONIZATION OF THE CROSS BORDER TRANSACTIOINS: CONCEPTUAL REVIEW OF ISLAMIC BANKING INDUSTRIES. International Journal of Shari'ah and Corporate Governance Research, 3(2), I-9. https://doi.org/I0.4628I/ijscgr.v3i2.838

Bhuiyan, A. B., Ismail, A. G., Islam, K. M. A., Noor, A. H. M., Solaiman, M., \& Rahman, M. A. (2020). Islamic Bank Safety Net Issues: The Regulatory Challenges for Cross Border Islamic Banking Transactions. International Journal of Islamic Business \& Management, 4(2), 20-3I. https://doi.org/I0.4628I/ijibm.v4i2.840

Islam, K. M. A., Khan, M. A. U., Azhar, S., Ahmed, M. R., Khurram, S., Masood, H., \& Farooq, L. (2020). COMPARISON OF IN VITRO ACTIVITY OF COLISTIN WITH CEFTOLOZANE/TAZOBACTAM AGAINST MULTI DRUG RESISTANT PSEUDOMONAS AERUGINOSA “A LAST LINE TREATMENT AGAINST MDR”. American International Journal of Multidisciplinary Scientific Research, 6(3), I-7. https://doi.org/I0.4628I/aijmsr.v6i3.823

Hassan, M. S., Mizanuzzaman, M., \& Islam, K. M. A. (2020). The Effects of Training to the Employee Performance and Development: A Study of Fareast Islami Life Insurance Company Limited, Bangladesh. International Journal of Business and Management Future, 4(2), I7-40. https://doi.org/I0.4628I/ijbmf.v4i2.785

\section{Copyrights}

Copyright for this article is retained by the author(s), with first publication rights granted to the journal. This is an open-access article distributed under the terms and conditions of the Creative Commons Attribution license (http://creativecommons.org/licenses/by/4.0/). 